e-ISSN: 2721-3013, p-ISSN: 2721-3005

DOI: https://doi.org/10.38035/jafm.v1i4

Received: 13 Agust 2020, Revised: 28 Agust 2020, Publish: 29 September 2020 https://creativecommons.org/licenses/by/4.0/

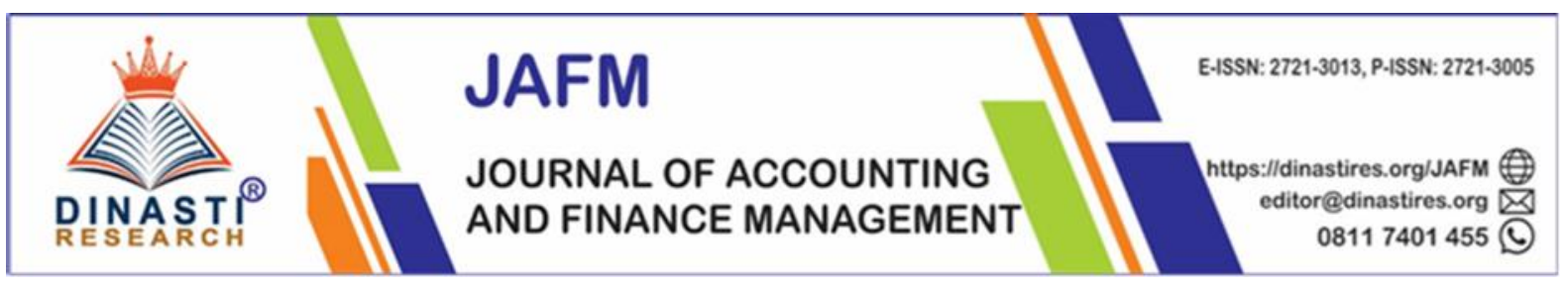

\title{
The Influence of Capital Structure and Managerial Ownership on Company Performance Through Agency Cost as Intervening Variables
}

\section{Yamasitha}

Faculty of Economics and Business, University Putra Indonesia "YPTK" Padang, Sumatera Barat, Indonesia

*Corresponding Author: Yamasitha

\begin{abstract}
The purpose of this research is to examine the effect of capytal structure and managerial ownership on firm performance by agency cost as an the intervening variable. The sample used is a manufacturing company sector 4 (varoius industries) and sector 5 (goods industries consumsy) listed in Indonesia Stock Exchange in 2015-2019. Were selected in the sampling method of sample use purposive. The data use dissecondary data and the analysis methodusedis multiple regression path analyze method. The results showed that the independent variables capital structure has a negative effect on the agency cost, and managerial ownership has a negative effect on the agency cost. The independent variables capital structure has a negative effect on the firm performance and capital structure has a negative indirect effect on the firm performance by agency cost. The independent variables managerial ownership has no positive effect on the firm performance and managerial ownership has a negative indirect effect on the firm performance by agency cost. Agency cost has no negative effect on the firm performance.
\end{abstract}

Keywords: Capital Structure, Managerial Ownership, Firm Performance, Agency Cost

\section{INTRODUCTION}

At the moment the (capital investors) investment company that invests to, or form a a new business, with the purpose of achieving welfare profit and investors.Investors will have earned invested to companies that perusahaannnya good performance, and having future still good.To this the company to be able to return or producing profit from the implanted investors. One performance indicators the company is return on assets roa (ROA ). ROA is more presented the best interests of stockholders. Roa value an increasingly large show the good company performance.Investors like menguntungkan because the return rate high (sudana, 2011: 23) company with good financial performance generate profit so as to have the rate of return maximum investment high. 
Table 1. Company ROA

\begin{tabular}{|c|c|c|c|c|}
\hline \multirow{2}{*}{ Kodusahan } & \multicolumn{4}{|c|}{ ROA } \\
\cline { 2 - 5 } & $\mathbf{2 0 1 4}$ & $\mathbf{2 0 1 5}$ & $\mathbf{2 0 1 6}$ & $\mathbf{2 0 1 7}$ \\
\hline ADHI & $3.17 \%$ & $2.77 \%$ & $1.57 \%$ & $1.82 \%$ \\
\hline AISA & $5.13 \%$ & $4.12 \%$ & $7.77 \%$ & $-9.71 \%$ \\
\hline CEKA & $3.19 \%$ & $7.17 \%$ & $17.51 \%$ & $7.71 \%$ \\
\hline INDF & $5.99 \%$ & $4.04 \%$ & $6.41 \%$ & $5.85 \%$ \\
\hline MYOR & $3.98 \%$ & $11.02 \%$ & $10.75 \%$ & $10.93 \%$ \\
\hline UNVR & $40.18 \%$ & $37.20 \%$ & $38.16 \%$ & $37.05 \%$ \\
\hline
\end{tabular}

Source: www.idx.ac.id

Based on table above it can be seen that the increase and decrease in roa each of the enterprises. Seen from data roa code company adhi, the decline from year 2014 until 2017. From the data roa code company aisa a decline in from year 2014 until 2017, it even happened minus in 2017. From the data roa code company ceka the increase in 2014, 2015, and 2016 who increasing the company performance. But in 2017 happen again the decline in .From the data roa code company it the increase and decrease in every year. From the data roa code prusahaan myor in 2014 to year 2015 there was an increase in, the beginning of 3.98 $\%$ to $11.02 \%$. But on 2016 and 2017 a decline in. From the data roa code company unvr the increase and decrease in every year.

Based on its financial report investors may know the performance of the company and the company in profit or profit. For a corporate investor capable of yielding high for what invested, be attraction to investors. An indicator that can be used in the process of the analysis is financial investors ratio or ratio a financial .Financial performance reflects the company in producing gain was the ratio profitability return on equity (ROE) used for indicating the level of return produced by the management of capital derived from owners and shareholders. The higher roe means more effectively and efficiently the company uses capital and investor confidence in investing the higher and have an impact on share prices. This must be considered by investors in choosing stocks.

There are some function in the company, among other functions of management and function .Separation of management function and function was vulnerable to conflicts of interest. This occurred because the result of the separation of functions as the owners and management companies. If however the shares owned by a manager, and is likely to keagenan problems occur. Where manager will take action to benefit themselves.

Problems can labor costs the agency. Is like a bonus of the money to the management and costs to be issued to supervision to prevent loss.Agency cost also can be defined as the use of cash flow for the accumulated nonessential which done by manager for free cash flow (cash flow management available for diskresioner used).

Jensen and meckling provide alternatives in overcome behavior manager by using debts in capital structure company. If a company a lot of debts, so manager will be forced eject streams of cash free to pay off debt. In this case the debt will be able to control the use of free cash flow to excess by manager to finance activities not optimal.

Agency cost also can be reduced by increasing managerial ownership.Managerial is ownership high can harmonize potential difference interests between shareholders out, management so problems keagenan assumed would be lost when a manager is as a pemiliki (jensen \& amp, meckling; 1976).

Based on the background on, problem then the researcher would want to examine the problem with title capital structure and ownership of managerial influence on the performance of the company through agency intervening as variable cost. 


\section{LITERATURE RIVIEW Agency Cost}

The theory keagenan discuss the relationship between agent and the principal. Where agent is management company manager, while the principal stock is a holder. The agent and the principal followed by an a contract stating the rights and obligations of each. The principal facilities and the money to run the company. The theory keagenan is due to the asymmetric information between principal and agent, asymmetric interest between principal and agent and because of the are unobservable behavior or bounded rationality. By the presence of all these three things then between agents will be principal and welfare of each. Agents will be trying to maximize welfare has a great compensation with love. Meanwhile the holder of will maximize welfare through the distribution of dividend that is to be maximized.

\section{Company Performace}

Utari (2016), the company performance is produced by a corporation in a particular period with reference to standards set.The company performance should be an results can be gauged and described the conditions of various sizes empirical an enterprise agreed.

Fahmi (2013) financial performance is a analysis undertaken to see the extent to which a companies have execute with use the implementation of financial well and properly. As by making a appendix financial that have met the standards and provisions in SAK (the accounting standard) or GAAP (General Acepted Accounting Principle), and other.

\section{Relationship between Financial Ratios and Company Performance}

Relations the ratio financial and the company performance according to Fahmi (2013) that the ratio financial and the company performance have a close relation. The ratio financial there are many their number and every the ratio had its usefulness. To investors he shall see the ratio with the use of most appropriate with analysis will he do. If the ratio was not presented the purpose of analysis will he did then the ratio are not will be used .

\section{Capital Structure}

Fahmi ( 2013: 179 ) that capital structure was an image from the capital are between the financial company owned by long-term debt and their own capital (shareholder's equity) to the financing of a company.

\section{Managerial ownership}

Managerial ownership is a company where the owner of management as well as in an enterprise, in other words the owner of direct business management inflicted. Managerial ownership can be measured by means of identify whether there will be names on a list the ownership structure entered on the board of commissioners and board of directors (Sari , 2015).The large proportion of the managerial ownership in the company and the management will strive harder for the benefit of shareholders but is themselves 


\section{Framework of Mind}

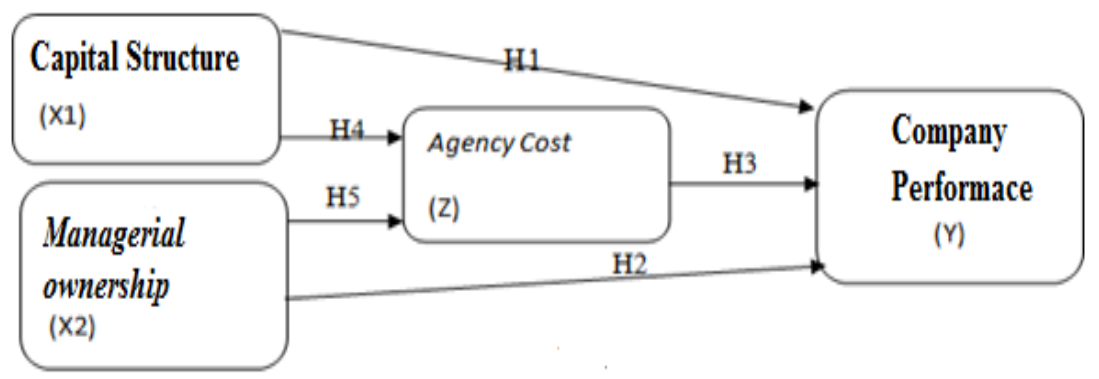

Figure 1. Conceptual Framework

\section{RESEARCH METHODOLOGY \\ Research Design}

According to Sugiyono (2017) research design is a scientific way to get data with specific purposes and uses. This research is a quantitative study where secondary data is used from the annual financial statements of manufacturing companies listed on the Indonesia Stock Exchange.Variabel penelitian

\section{Population and Samples}

The population that will be the object of this research is manufacturing companies in sector 4 of various industries and sector 5 of the consumer goods industry that go public on the Indonesia Stock Exchange (IDX) which publishes annual reports published during 2015 2019 where the number of manufacturing companies is sector 4 and sector 5 . As many as 85 companies. The sample research was carried out by purposive sampling method, meaning that the sample was selected based on the subjective considerations of the study where the requirements made as criteria must be met as a sample.

As for the sample selection criteria are as follows:

1. Manufacturing companies in various sectors of various industries and sector 5 of the consumer goods industry listed on the Indonesia Stock Exchange from 2015-2019.

2. The company published financial reports for 5 consecutive years, namely 2015,2016 , 2017, 2018 and 2019.

3. Companies that did not experience losses during the observation period, namely 2015, 2016, 2017, 2018, and 2019.

4. Present financial reports in rupiah units.

5. Available data required in full

\section{Dependent Variable}

Company Performace

One measure of company performance is Return On Asset (ROA). The following is the ROA formula used in this study

$$
R O A=\frac{\mathrm{EAT}}{\text { total asset }} \times 100 \%
$$

\section{Independent Variable Modal Structure}

Analysis of capital structure can be measured through debt ratio analysis(leverage), which is how much the company is financed with debt. The following is the ratio used by the debt to total assets or debt ratio : 


\section{Managerial $O$ wnership}

$$
\text { DAR }=\frac{\text { Total liabilities }}{\text { Total assets }}
$$

Managerial share ownership is the proportion of shares commonly owned by management, which can be measured from the percentage of ordinary shares owned by management who are actively involved in decision making:

$$
\text { MO }=\frac{\text { the number of shares owned by commissioners and management }}{\text { the number of shares outstanding }} \times 100 \%
$$

\section{Independent Variable}

Discretionary Expense

The agency cost proxy used is the discretionary expense ratio, which is the expense incurred at the discretion of a manager. This expense includes operating expenses, nonoperating expenses, interest expenses, and salaries and wages. The formula is as follows:

$$
\mathrm{AG}=\frac{\text { discretion ary expense }}{\text { Net Sales }}
$$

\section{RESULTS AND DISCUSSION \\ Descriptive Statistics}

Descriptive statistics in this study are used to provide information about research variables such as Agency Cost (Y1), ROA (Y2), DAR (X1), and Managerial Ownership (X2). In addition, the purpose of the results of this descriptive statistical test is to see the quality of research data aimed at the numbers or values contained in the mean and standard deviation. It can be said that if the mean is greater than the standard deviation or deviation then the data quality is better.

Table 2. Descriptive statistics for the research variables can be seen as follows:

\begin{tabular}{|l|r|r|r|r|r|}
\hline & N & Minimum & Maximum & Mean & Std. Deviation \\
\hline ROA_Y2 & 170 & .04 & 42.13 & 11.4637 & 9.94699 \\
AG_Y1 & 170 & .03 & .49 & .2063 & .11766 \\
DAR_X1 & 170 & .00 & .88 & .3906 & .18149 \\
KM_X2 & 170 & .00 & 11.49 & 1.5481 & 3.16725 \\
ValidN (listwise) & 170 & & & & \\
\hline
\end{tabular}

The ROA variable with the number of data $(\mathrm{N})$ is 170 , has a minimum value of 0.04 and a maximum value of 42.13. The average value (mean) is 11.4637 and the standard deviation is 9,94699. The AG (Agency Cost) variable with the amount of data $(\mathrm{N})$ is 170 , has a minimum value of 0.03 and a maximum value of 0.49 . The average value (mean) is 0.2063 and the standard deviation is 0.11766 . The DAR variable with the number of data $(\mathrm{N})$ is 170 , has a minimum value of 0.00 and a maximum value of 0.88 . The average value (mean) is 0.3906 and the standard deviation is 0.18149 . The KM (Managerial Ownership) variable with 170 data $(\mathrm{N})$ has a minimum value of 0.00 and a maximum value of 11.49 . The average value (mean) is 1.5481 and the standard deviation is 3.16725 .

\section{Outlier Test}

The outlier test is a test used to detect data that deviates too far from other data in a series of data (outlier data). The existence of outlier data in a data set will make the analysis of a series of data be biased or not reflect the actual phenomenon. 
One way to detect the presence of outliers in each research variable is the Grubbs test method. In this method, it will compare the $Z$ value with the critical value of $Z$ with a significance level of $5 \%$. If $\mathrm{Z}>\mathrm{Z}$ is critical, then null hypothesis is accepted or an outlier is detected. For the Zcritical value has been given by the statistical table based on the number of observations, the number of observations of 34 sample companies from 2015-2019 is 170 observations. The $\mathrm{Z}$ critical value of 170 observations is 2.96531404639 . Meanwhile, to find the $\mathrm{Z}$ value, you can use the help of the outlier calculator application on the GrapPad software website.

\section{Classical Assumption Test Results Normality Test}

The normality test aims to determine whether the residual model has normal distribution or not. The test method uses graph test and for calculations using the IBM SPSS Statistic 22 program. The results of the normality test in this study are presented in the figure:

a. The first test is Capital Structure (X1), and Managerial Ownership (X2) on Agency Cost (Y1).

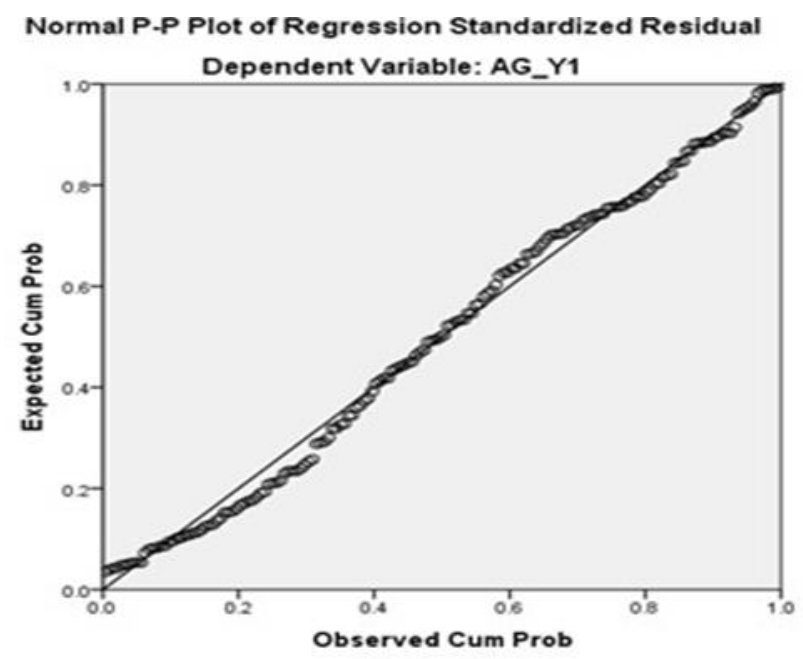

Based on the test results of the Normal P-P Plot Regression Standardized Graph in the figure, it can be seen that the dots spread out on a diagonal line. Therefore, based on the normality test, regression analysis is feasible.

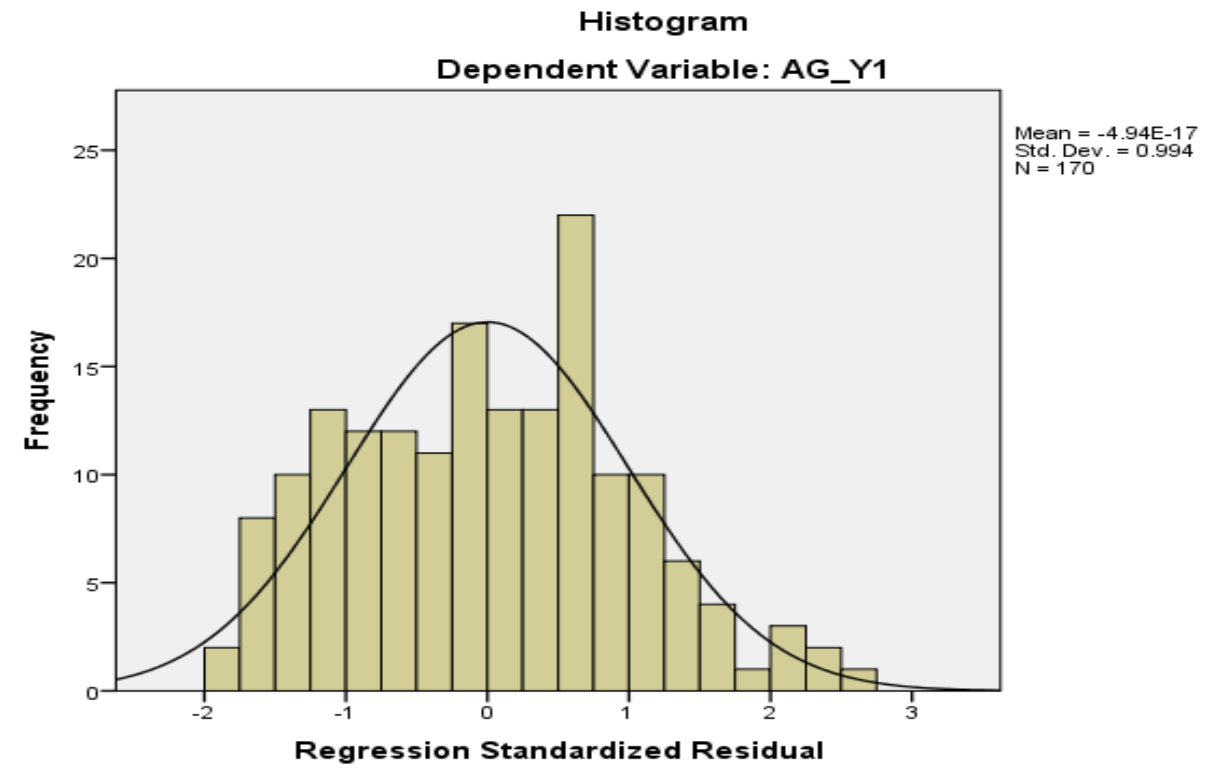


Based on the results of the Histogram Graph test in the figure, it can be seen that the dependent and regression standardized residual curves form a bell-like image. Therefore, based on the normality test, regression analysis is feasible.

b. The second test of Capital Structure (X1) and Managerial Ownership (X2) on Company Performance through Agency Cost.

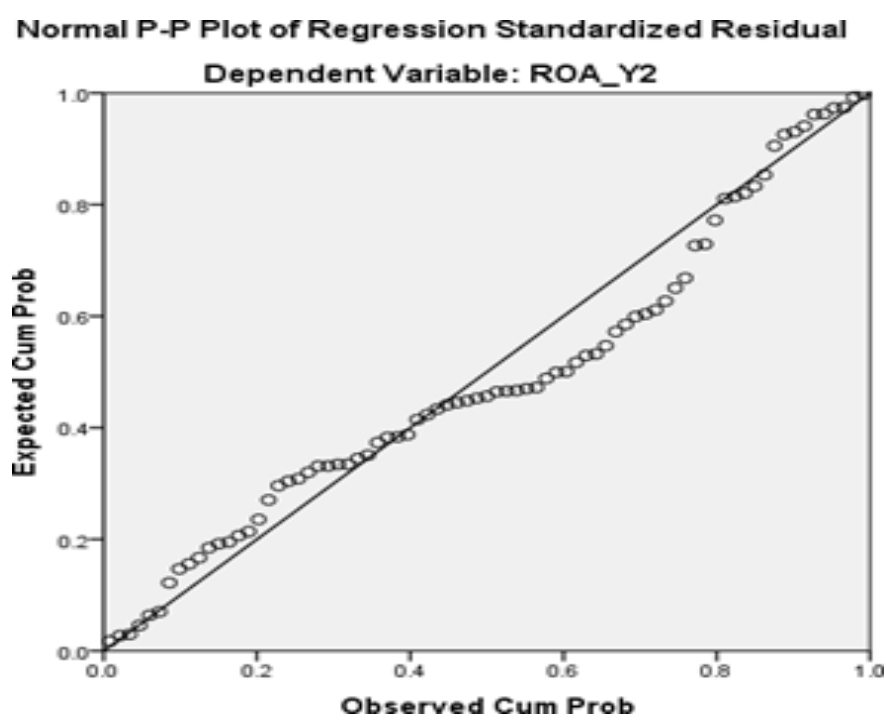

Based on the test results of the Normal P-P Plot Regression Standardized Graph in the figure, it can be seen that the dots spread around the diagonal line. Therefore, based on the normality test, regression analysis is feasible even though there are a few plots that deviate from the diagonal line.

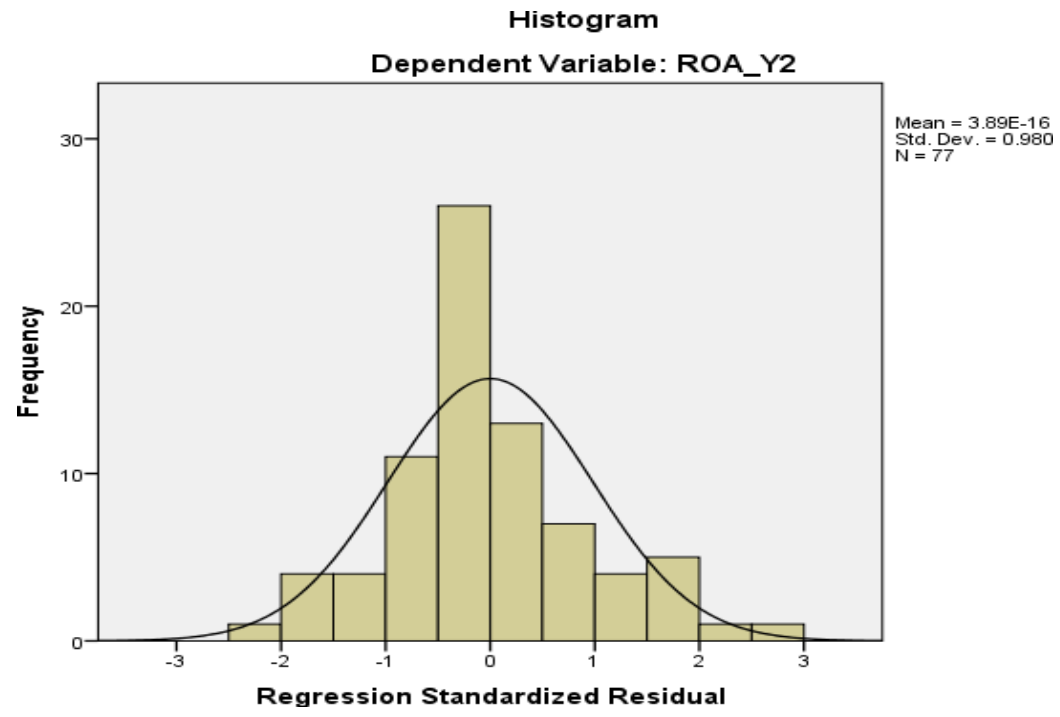

Based on the results of the Histogram Graph test in the figure, it can be seen that the dependent and regression standardized residual curves form a bell-like image. Therefore, based on the normality test, regression analysis is feasible even though there is a slope.

\section{Heteroscedasticity Test}

Based on the results of heteroscedasticity testing, a summary of the results is shown in the table below: 
a. The first test is Capital Structure (X1), and Managerial Ownership (X2) on Agency Cost (Y1).

Table 3. Coefficients Detemination

\begin{tabular}{|c|c|c|c|c|c|c|}
\hline \multicolumn{7}{|c|}{ Coefficients $^{\mathrm{a}}$} \\
\hline \multirow{2}{*}{\multicolumn{2}{|c|}{ Model }} & \multicolumn{2}{|c|}{ Unstandardized Coefficients } & \multirow{2}{*}{$\begin{array}{c}\begin{array}{c}\text { Standardized } \\
\text { Coefficients }\end{array} \\
\text { Beta } \\
\end{array}$} & \multirow[b]{2}{*}{$\mathrm{T}$} & \multirow[b]{2}{*}{ Sig. } \\
\hline & & B & Std. Error & & & \\
\hline \multirow[t]{3}{*}{1} & (Constant) & -5.237 & .749 & & -6.990 & .000 \\
\hline & DAR_In $\times 1$ & .880 & .570 & .175 & 1.545 & .127 \\
\hline & $\mathrm{KM}$ In $\times 2 \mathrm{~g}$ & -.156 & .122 & -145 & -1.275 & .206 \\
\hline
\end{tabular}

From the table above, it can be seen that in the first regression model there are no symptoms of heteroscedasticity. This is because the sig value of the Ln Capital Structure (DAR) variable against Ln U2 is 0.127>0.05, while the Ln Managerial Ownership (KM) variable against $\mathrm{Ln} \mathrm{U} 2$ is $0.206>0.05$.

b. The second test of Capital Structure (X1) and Managerial Ownership (X2) on Company Performance through Agency Cost.

Table 4. Coefficients Detemination

\begin{tabular}{|c|c|c|c|c|c|c|}
\hline \multirow{2}{*}{\multicolumn{2}{|c|}{ Model }} & \multicolumn{2}{|c|}{ Unstandardized Coefficients } & \multirow{2}{*}{$\begin{array}{c}\text { Standardized } \\
\text { Coefficients } \\
\text { Beta }\end{array}$} & \multirow[b]{2}{*}{$T$} & \multirow[b]{2}{*}{ Sig. } \\
\hline & & $\mathrm{B}$ & Std. Error & & & \\
\hline \multirow[t]{4}{*}{1} & (Constant) & 3.239 & 1.387 & & 2.336 & .022 \\
\hline & AG_InY1g & .237 & .452 & .075 & .525 & .601 \\
\hline & DAR_InX1 & .501 & .534 & .128 & .938 & .352 \\
\hline & $\mathrm{KM}$ In X $2 \mathrm{~g}$ & .024 & .107 & .028 & 221 & .826 \\
\hline
\end{tabular}

From the table above, it can be seen that in the second regression model there are no symptoms of heteroscedasticity. This is because the sig value of the Ln Agency Cost (AG) variable against Ln U2 is 0.601>0.05. The variable Ln Capital Structure (DAR) to Ln U2 was 0.127>0.05, while the Ln Managerial Ownership (KM) variable against Ln U2 was $0.206>0.05$.

\section{Multicollinearity Test}

The tolerance value limit is 0.1 and the VIF limit is 10 . If the tolerance value is $<0.1$ or VIF> 10, multicollinearity occurs. Conversely, if the tolerance value is $>0.1$ or VIF $<10$ then there is no multicollinearity. Based on the results of the multicollinearity test that has been carried out, a summary of the results is shown in the table below:

a. The first test is Capital Structure (X1), and Managerial Ownership (X2) on Agency Cost (Y1).

Table 5. Coefficients Detemination

\begin{tabular}{|c|c|c|c|c|c|c|c|}
\hline \multirow[b]{3}{*}{ Model } & \multicolumn{7}{|c|}{ Coefficients } \\
\hline & \multicolumn{2}{|c|}{$\begin{array}{c}\text { Unstandardized } \\
\text { Coefficients }\end{array}$} & \multirow{2}{*}{$\begin{array}{c}\text { Standardize } \\
\text { d } \\
\text { Coefficients }\end{array}$} & \multirow[b]{2}{*}{$\mathrm{T}$} & \multirow[b]{2}{*}{ Sig. } & \multicolumn{2}{|c|}{ Collinearity Statistics } \\
\hline & $\mathrm{B}$ & Std. Error & & & & Tolerance & VIF \\
\hline (Constant) & .297 & .022 & & 13.693 & .000 & & \\
\hline DAR_X1 & -.189 & .048 & -.291 & -3.952 & .000 & .952 & 1.051 \\
\hline $\mathrm{KM} \_\mathrm{X} 2$ & -.011 & .003 & -.303 & -4.110 & .000 & .952 & 1.051 \\
\hline
\end{tabular}

a. Dependent Variable:AG_Y1

Based on the output table above, the Coefficient shows that the Tolerance value of the Capital Structure variable (DAR) and the Managerial Ownership (KM) variable is 0.952 , which means that the Tolerance value is greater than 0.1 , while the VIF (Variance 
Infloating Factor) value of the Capital Structure variable (DAR) and the Managerial Ownership (KM) variable of 1.051, where the VIF value is less than 10. The TOL and VIF values of the two variables in this case are the same, because in this regression model it only consists of two independent variables. So it can be concluded that there is no correlation between the independent variables or the absence of multicollinearity.

b. The second test of Capital Structure (X1) and Managerial Ownership (X2) on Company Performance through Agency Cost.

Table 5. Coefficients Detemination

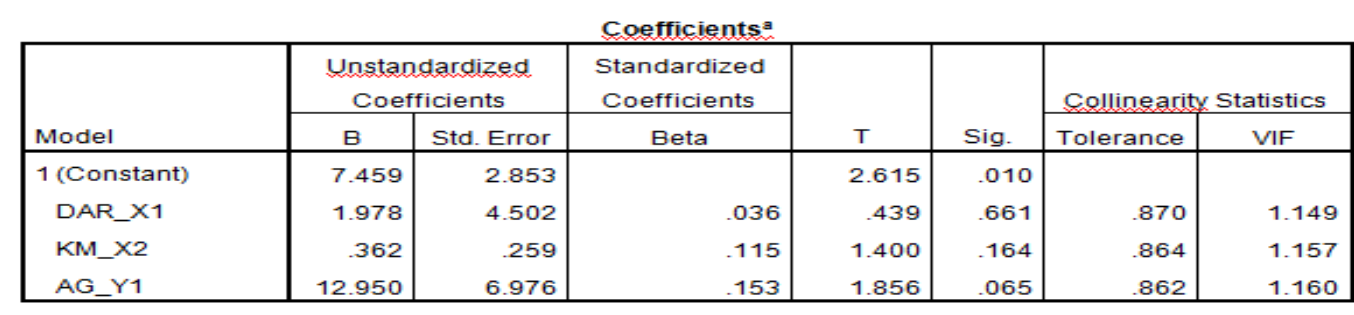

a. Dependent Variable:ROA_Y2

Based on the output table above, the Coefficient shows that the Tolerance value of the Capital Structure variable (DAR) is 0.870 , the Managerial Ownership (KM) variable is 0.864, and the Agency Cost (AG) variable is 0.862, where the value of each variable is large than 0.1. , while the VIF (Variance Infloating Factor) value of the Capital Structure variable (DAR) is 1.149, the Managerial Ownership (KM) variable is 1.157 , and the Agency Cost (AG) variable is 1.160 where the value of each variable is less than 10 . It can be concluded that that there is no correlation between the independent variables or the absence of multicollinearity.

\section{Auto correlation test}

Based on the test, the DW values are obtained as follows:

a. The first test of Capital Structure (X1), and Managerial Ownership (X2) to Agency Cost (Y1).

Table 6. R Square

\begin{tabular}{|l|r|r|r|r|r|}
\hline & & Model Summary & \\
Model & $R$ & R Square & $\begin{array}{c}\text { Adjusted } R \\
\text { Square }\end{array}$ & $\begin{array}{c}\text { Std. Error of the } \\
\text { Estimate }\end{array}$ & Durbin-Watson \\
\hline 1 & $.371^{\mathrm{a}}$ & .138 & .127 & .10991 & .527 \\
\hline
\end{tabular}

a. Predictors: (Constant), KM_X2, DAR_X1

b. Dependent Variable:AG_Y1

Based on the output table above, it can be seen that the Durbin-Watson value is 0.527 , which means that the Durbin-Watson value in this study is in the range -2 to +2 . So it can be concluded that there is no autocorrelation in this study.

b. The second test of Capital Structure (X1) and Managerial Ownership (X2) on Company Performance through Agency Cost.

Table 7. R Square

\begin{tabular}{|l|c|c|c|c|r|}
\hline Model & $R$ & R Square & $\begin{array}{c}\text { Adjusted R } \\
\text { Square }\end{array}$ & $\begin{array}{c}\text { Std. Error of the } \\
\text { Estimate }\end{array}$ & Durbin-Watson \\
\hline 1 & $.159^{\mathrm{a}}$ & .025 & .008 & 9.90857 & .628 \\
\hline
\end{tabular}

a. Predictors: (Constant), AG_Y1, DAR_X1, KM_X2

b. Dependent Variable:ROA_Y2 
Based on the output table above, it can be seen that the Durbin-Watson value is 0.628 , which means that the Durbin-Watson value in this study is in the range -2 to +2 . So it can be concluded that there is no autocorrelation in this study.

\section{Panel Data Regression Analysis Results}

Multiple linear regression analysis is used to determine the effect or linear relationship between two or more independent variables and one dependent variable.

\section{a. Testing the first substructure of Capital Structure (X1), and Managerial Ownership} (X2) to Agency Cost (Y1)

Table 8. R Square

\begin{tabular}{|c|c|c|c|c|c|c|}
\hline \multicolumn{7}{|c|}{ Coefficients } \\
\hline \multirow{2}{*}{\multicolumn{2}{|c|}{ Model }} & \multicolumn{2}{|c|}{ Unstandardized Coefficients } & $\begin{array}{l}\text { Standardized } \\
\text { Coefficients }\end{array}$ & \multirow[b]{2}{*}{$\mathrm{t}$} & \multirow[b]{2}{*}{ Sig. } \\
\hline & & B & Std. Error & Beta & & \\
\hline \multirow[t]{3}{*}{1} & (Constant) & 297 & .022 & & 13.693 & .000 \\
\hline & DAR_X1 & -.189 & .048 & -.291 & -3.952 & .000 \\
\hline & $\mathrm{KM} \mathrm{M}_{2} 2$ & -.011 & .003 & -.303 & -4.110 & .000 \\
\hline
\end{tabular}

Based on the selected estimation model, the panel data regression model equation is obtained as follows:

$\mathrm{AC}=\mathbf{- 0 . 2 9 1} \mathrm{DAR}-0.303 \mathrm{KM}+$ et

1. The regression coefficient of the Capital Structure variable is -0.291 , which means that if the Capital Structure increases by 1\%, the Agency Cost will decrease by 0.291 , assuming that other independent variables are of fixed value.

2. The variable coefficient of Managerial Ownership is -0.303 , which means that if Managerial Ownership increases by $1 \%$, the Agency Cost will decrease by 0.303 , assuming other independent variables are of fixed value.

b. The second test of Capital Structure (X1), Managerial Ownership (X2), and Agency Cost (Y1) on Company Performance (Y2)

Table 9. R Square

\begin{tabular}{|c|c|c|c|c|c|c|}
\hline \multirow{2}{*}{\multicolumn{2}{|c|}{ Model }} & \multicolumn{2}{|c|}{ Unstandardized Coefficients } & \multirow{2}{*}{$\begin{array}{c}\text { Standardized } \\
\text { Coefficients } \\
\text { Beta } \\
\end{array}$} & \multirow[b]{2}{*}{$t$} & \multirow[b]{2}{*}{ Sig. } \\
\hline & & B & Std. Error & & & \\
\hline \multirow[t]{4}{*}{1} & (Constant) & 14.979 & 2.127 & & 7.041 & .000 \\
\hline & AG_logY1 & .550 & 2.712 & .028 & .203 & .840 \\
\hline & DAR_X1 & -11.558 & 4.930 & -.303 & -2.344 & .022 \\
\hline & $\mathrm{KM}$ _log $\times 2$ & 1.020 & .623 & .193 & 1.639 & .106 \\
\hline
\end{tabular}

Based on the selected estimation model, the panel data regression model equation is obtained as follows:

ROA = -0,303 DAR + 0.193 KM + 0.028 AG + et

1. The Agency Cost variable regression coefficient is 0.028 , which means that if the Agency Cost increases by $1 \%$, the Company's performance will increase by 0.028 , assuming that the other independent variables are of fixed value.

2. The regression coefficient of the Capital Structure variable is -0.303 , which means that if the Capital Structure has increased by 1\%, the Company's performance will decrease by 0.303 , assuming other independent variables are of fixed value.

3. The regression coefficient of the Managerial Ownership variable is 0.193, which means that if the Managerial Ownership has increased by 1\%, the Company's Performance will increase by 0.193 , assuming other independent variables have a fixed value. 


\section{Path Analysis Calculation}

To test the effect of the intervening variables, the path analysis method is used. The magnitude of the direct effect can be seen directly in the regression coefficient value, while the magnitude of the indirect effect is calculated by multiplying the indirect coefficient.

a. Direct Effect (Direct Effect or DE)

1. The effect of capital structure on agency cost is -0.291

2. The effect of managerial ownership on agency cost is -0.303

3 . The effect of capital structure on company performance is -0.303

4. The effect of managerial ownership on company performance is 0.193

5. The effect of agency cost on company performance is 0.028

b. Indirect Effect

1. Capital structure on company performance through agency cost of $(-0.291 \times 0.028)-$ 0.008148

2. Managerial ownership of firm performance through agency cost is $(-0.303 \times 0.028)$ 0.008484

c. Total Effect

1. Capital structure on firm performance through agency cost of $[-0.303+(-0.291 \mathrm{x}$ $0.028)]-0.311148$

2. Managerial ownership of firm performance through agency cost is $[0.193+(-0.303 \mathrm{x}$ $0.028)] 0.18451$

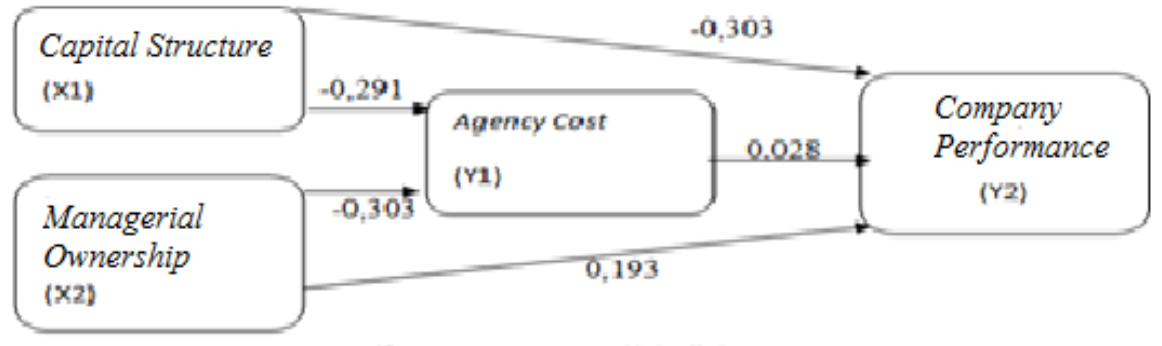

Figure 2. Indirect Effect

So it can be interpreted that the direct effect of capital structure on firm performance is greater than the indirect effect of capital structure on firm performance $(-0.303>$ 0.008148). So it can be interpreted that the direct effect of managerial ownership on firm performance is greater than the indirect effect of managerial ownership on firm performance $(0.193>-0.008484)$

\section{Hypothesis Test Results}

Simultaneous Hypothesis Testing Results (Test F)

The results of the F test can be seen in the table below:

a. Testing the first substructure of Capital Structure (X1) and Managerial Ownership (X2) together on Agency Cost (Y1).

Table 10. R Square ANOVA:

\begin{tabular}{|ll|r|r|r|r|r|}
\hline Model & & Sum of Squares & \multicolumn{1}{c|}{ Df } & Mean Square & F & Sig. \\
\hline 1 & Regression & 322 & 2 & .161 & 13.327 & $.000^{\circ}$ \\
& Residual & 2.018 & 167 & .012 & & \\
& Total & 2.340 & 169 & & & \\
\hline
\end{tabular}

a. Dependent Variable:AG_Y1

b. Predictors: (Constant), KM_X2, DAR_X1

Based on the table above, it shows the results of the F test, namely $\mathrm{F}$ count greater than $\mathrm{F}$ table with a value of $13.327>3.05$. In addition, it can be seen that the significance 
probability value is 0.000 or less than $0.05(0.000<0.05)$. This shows that the capital structure and managerial ownership variables together have a significant positive effect on agency cost.

b. The second test is Capital Structure (X1), Managerial Ownership (X2) and Agency Cost (Y1) jointly on Company Performance

\begin{tabular}{ll|r|r|r|r|r|}
\hline \multicolumn{1}{|l|}{ Model } & Sum of Squares & \multicolumn{1}{c|}{ Df } & Mean Square & F & Sig. \\
\hline 1 & Regression & 331.548 & 3 & 110.516 & 3.962 & $.011^{\circ}$ \\
& Residual & 2036.351 & 73 & 27.895 & & \\
& Total & 2367.899 & 76 & & & \\
\hline
\end{tabular}
a. Dependent Variable: ROA_Y2
b. Predictors: (Constant), KM_logX2,DAR_X1, AG_logY1

Based on the table above, it shows the results of the $\mathrm{F}$ test, namely $\mathrm{F}$ count greater than $\mathrm{F}$ table with a value of 3,962> 2.66. In addition, it can be seen that the significance probability value is 0.011 or less than $0.05(0.011<0.05)$. This shows that the variables of capital structure, managerial ownership, and agency cost together have a significant positive effect on company performance.

\section{Result of Partial Hypothesis Testing (t test)}

The $t$ test results can be seen in the table below:

\section{a. Regression analysis results for substructure testing 1}

1. The effect of capital structure on agency cost

The effect of capital structure on agency cost hypothesis testing using significance test can be done by comparing $t$ count with $t$ table or by comparing the significance probability value of 0.05 . Based on the table, it can be seen that the value is $-3,952$ while the $t$ table at a significance of 0.05 is 1.65408 so that $t$ count $<t$ table (3.952> 1.65408). In addition, it can be seen that the significance probability value is 0.000 or less than $0.05(0.000<0.05)$ Ho is rejected and $\mathrm{H} 1$ is accepted. Based on the results of the hypothesis test above, it can be concluded that the capital structure variable has a negative effect on agency cost.

2. The effect of managerial ownership on agency cost

Hypothesis testing using the significance test can be done by comparing $t$ count with $t$ table or by comparing the significance probability value of 0.05 . Based on the $t$ table, it can be seen that the $t$ value is -4.110 while the $t$ table at a significance of 0.05 is 1.65408 so that $t$ count $<$ table $(-4.110<1.65408)$. In addition, it can be seen that the significance probability value is 0.000 or less than $0.05(0.000<0.05)$ Ho is rejected and $\mathrm{H} 2$ is accepted. Based on the results of the hypothesis test above, it can be concluded that the managerial ownership variable has a negative effect on agency cost.

\section{b. Regression analysis results for substructure testing 2}

1. The effect of capital structure on company performance

Hypothesis testing using the significance test can be done by comparing $t$ count with $t$ table or by comparing the significance probability value of 0.05 . Based on the $t$ table, it can be seen that the $t$ value is -2.344 while the $t$ table at a significance of 0.05 is 1.65408 so that $\mathrm{t}$ count $<\mathrm{t}$ table $(-2.344<1.65408)$. In addition, it can be seen that the significance probability value is 0.022 or less than $0.05(0.022<0.05)$ Ho is rejected and $\mathrm{H} 3$ is accepted. Based on the results of the hypothesis test above, it can be concluded that the capital structure variable has a negative effect on company performance

2. The influence of managerial ownership on company performance

Hypothesis testing using the significance test can be done by comparing $t$ count with $t$ table or by comparing the significance probability value of 0.05 . Based on the $t$ 
table, it can be seen that the $t$ value is 1.639 while the $t$ table at a significance of 0.05 is 1.65408 so that $t$ count $<\mathrm{t}$ table $(1.639<1.65408)$. In addition, it can be seen that the significance probability value is 0.106 or greater than $0.05(0.106>0.05)$ Ho is accepted and $\mathrm{H} 4$ is rejected. Based on the results of the hypothesis test above, it can be concluded that the managerial ownership variable has no positive effect on company performance.

3. The effect of agency cost on company performance

Hypothesis testing using the significance test can be done by comparing $\mathrm{t}$ count with $t$ table or by comparing the significance probability value of 0.05 . Based on the $t$ table, it can be seen that the $t$ value is 0.203 while the $t$ table at a significance of 0.05 is 1.65408 so that $t$ count $<\mathrm{t}$ table $(0.203<1.65408)$. In addition, it can be seen that the significance probability value is 0.840 or greater than $0.05(0.840>0.05)$ Ho is accepted and $\mathrm{H} 5$ is rejected. Based on the results of the hypothesis test above, it can be concluded that the agency cost variable does not have a negative effect on company performance.

\section{Result of Determination Coefficient Test $\left(\mathbf{R}^{\mathbf{2}}\right)$}

The coefficient of determination test results can be seen in the table below:

a. Testing the first substructure of Capital Structure (X1), and Managerial Ownership (X2) to Agency Cost (Y1)

\begin{tabular}{|c|c|c|c|c|}
\hline Model & $\mathbf{R}$ & R Square & $\begin{array}{l}\text { Adjusted R } \\
\text { Square }\end{array}$ & $\begin{array}{c}\text { Std. Error of the } \\
\text { Estimate }\end{array}$ \\
\hline 1 & $371^{a}$ & .138 & .127 & .10991 \\
\hline
\end{tabular}

From the table above, because the independent variable is more than one, we can see the column R Square $=0.138$ or $13.8 \%$. This means that $13.8 \%$ of agency cost can be explained by variations in the independent variables, namely capital structure and managerial ownership, the remaining $86.2 \%(100 \%-13.8 \%)$ is explained by other causes outside the model.

b. The second test of Capital Structure (X1), Managerial Ownership (X2), and Agency Cost (Y1) on Company Performance (Y2)

\begin{tabular}{|c|c|c|c|c|}
\hline \multicolumn{5}{|c|}{ Model Summary } \\
\hline Model & $\mathrm{R}$ & R Square & $\begin{array}{c}\text { Adjusted R } \\
\text { Square } \\
\end{array}$ & $\begin{array}{c}\text { Std. Error of the } \\
\text { Estimate }\end{array}$ \\
\hline 1 & $374^{a}$ & 140 & .105 & 5.28159 \\
\hline
\end{tabular}

From the table above, because the independent variable is more than one, we can see the column R Square $=0.140$ or $14 \%$. This means that $14 \%$ of the company's performance can be explained by variations in the independent variables, namely capital structure, managerial ownership, and agency cost, the remaining $86 \%(100 \%-14 \%)$ is explained by other causes outside the model

\section{Discussion of Research Results}

From the results of this analysis, the following matters can be discussed:

\section{The Effect of Capital Structure on Agency Cost}

Based on the table of the results of the $t$ test calculation, it can be seen that the $t$ value is $-3,952$ while the $t$ table at a significance of 0.05 is 1.65408 so that $t$ count $<t$ table $(-3,952<1.65408)$. In addition, it can be seen that the significance probability value is 0.000 or less than $0.05(0.000<0.05)$ Ho is rejected and H1 is accepted. Thus the capital structure variable has a significant negative effect on agency cost. Based on the calculation 
of path analysis, it shows that the capital structure directly affects the agency cost of 0.189 . The results of this study are in line with the results of research conducted by (Putri, 2017) which shows that capital structure has a negative effect on agency cost.

\section{The Effect of Managerial Ownership on Agency Cost}

Based on the t-test calculation results table, it can be seen that the $t$ value is -4.110 while the $\mathrm{t}$ table at a significance of 0.05 is 1.65408 so that $\mathrm{t}$ count $<\mathrm{t}$ table $(-4.110$ $<1.65408$ ). In addition, it can be seen that the significance probability value is 0.000 or less than $0.05(0.000<0.05) \mathrm{Ho}$ is rejected and $\mathrm{H} 2$ is accepted. Thus, managerial ownership has a significant negative effect on agency cost. Based on the calculation of path analysis, it shows that managerial ownership directly affects the agency cost of 0.011. The results of this study are in line with the results of research conducted by (Putri, 2017) where institutional ownership and concentrated ownership have a negative effect on agency cost. Institutional ownership replaces managerial ownership in controlling agency cost.

\section{The Effect of Capital Structure on Company Performance}

Based on the t-test calculation results table, it can be seen that the $t$ value is -2.344 , while the $t$ table at a significance of 0.05 is 1.65408 so that $t$ count $<\mathrm{t}$ table $(-2.344$ $<0.203)$. In addition, it can be seen that the significance probability value is 0.022 or less than $0.05(0.022<0.05)$ Ho is rejected and H3 is accepted. Thus the capital structure variable has a significant negative effect on company performance. Based on the calculation of path analysis, it shows that the capital structure directly affects the company's performance by $-11,558$. The results of this study are in line with the results of research conducted by (Dawar, 2014) on the relationship between debt (both short and long term) and company profitability; the debt coefficient becomes negative, which indicates that an increase in debt is associated with a decrease in profitability (or performance).

\section{The Effect of Managerial Ownership on Company Performance}

Based on the table $t$ test calculation results, it can be seen that the $t$ value is 1.639 while the $t$ table at a significance of 0.05 is 1.65408 so that $t$ count $<$ t table $(1.639$ $<1.65408$ ). In addition, it can be seen that the significance probability value is 0.106 or greater than $0.05(0.106>0.05)$ Ho is accepted and $\mathrm{H} 4$ is rejected. Thus the managerial ownership variable does not have a positive effect on company performance. Based on the calculation of path analysis, it shows that managerial ownership directly affects the company's performance by 1.020 . The results of this study are in line with the results of research conducted by (Rani, 2015), it is found that the significance value of the managerial variable coefficient is not significant, so it can be explained that the managerial ownership variable does not have a significant effect on ROA. And in line with research (Widyati, 2013) that managerial ownership does not have a significant effect on financial performance, because the proportion of share ownership by managers in companies is still very small, so it is possible that managers have not felt the benefits of this ownership.

\section{Effect of Agency Cost on Company Performance}

Based on the table of the results of the $t$ test calculation, it can be seen that the $t$ value is 0.203 while the $t$ table at a significance of 0.05 is 1.65408 so that $t$ count $<t$ table $(0.203<1.65408)$. In addition, it can be seen that the significance probability value is 0.840 or greater than $0.05(0.840>0.05)$ Ho is accepted and H5 is rejected. Thus the agency cost variable does not have a negative effect on company performance. Based on the calculation of path analysis, it shows that agency cost directly affects company performance by 0.550 . The results of this study are in line with Alamsyah and (Muchlas, 
2017) agency cost partially and simultaneously has no significant effect on financial performance as measured by the Almant Z-Score.

6. Indirect influence of Capital Structure on Company Performance through Agency Cost as an intervening variable.

Based on the calculation results, it is known that the value of the direct effect is 0.303 and the indirect effect is -0.008148 . These results indicate that indirectly the capital structure through agency cost has an influence on company performance.

7. The indirect effect of Managerial Ownership on Company Performance through Agency Cost as an intervening variable.

Based on the calculation, it is known that the direct effect value is 0.193 and the indirect effect is -0.008484 . These results indicate that indirectly managerial ownership through agency costs has an influence on company performance.

\section{CONCLUSION AND SUGGESTION}

\section{Conclusion}

Based on the results of the research that has been carried out in the previous chapter, it can be concluded as follows:

1. Capital structure has a significant negative effect on agency cost in manufacturing companies in sector 4 (various industries) and sector 5 (consumer goods industry) which are listed on the Indonesia Stock Exchange in 2015-2019.

2. Managerial ownership has a significant negative effect on agency costs in manufacturing companies in sector 4 (various industries) and sector 5 (consumer goods industry) which are listed on the Indonesia Stock Exchange in 2015-2019.

3. Capital structure has a significant negative effect on company performance in manufacturing companies in sector 4 (various industries) and sector 5 (consumer goods industry) which are listed on the Indonesia Stock Exchange in 2015-2019.

4. Managerial ownership does not have a significant positive effect on company performance in manufacturing companies in sector 4 (various industries) and sector 5 (consumer goods industry) which are listed on the Indonesia Stock Exchange in 2015-2019.

5. Agency cost does not have a significant positive effect on company performance in manufacturing companies in sector 4 (various industries) and sector 5 (consumer goods industry) which are listed on the Indonesia Stock Exchange in 2015-2019.

6. Indirectly, capital structure through agency cost has an influence on company performance.

7. Indirectly, managerial ownership through agency cost has an influence on company performance.

\section{Suggestion}

By looking at the results of the discussion in the previous chapter, the suggestions that can be submitted are as follows:

1. For the Company

In the results of this study, the capital structure has a negative effect on agency cost, with the amount of debt used by the company, thereby reducing agency costs, but the high debt ratio will increase the company's dependence on external parties. And the high debt ratio will also affect the company's profitability because part of the income is used to pay debt, this will reduce the company's profitability ratio, so the company will consider the decision to use debt funding.

2. For Further Researchers

For the same research, it should be carried out in all manufacturing sectors, considering that this sector is a sector with complex activities and involves a wide variety 
of resources, activities, services, and various learning processes. In addition, it is also expected to add independent variables outside the research variables such as company size, institutional ownership, debt to equity ratio, and other variables and to increase the research period of more than 5 years, namely 8-10 years, given the changing national industrial policy factors. a change of power which is carried out every five years.

\section{REFERENCE}

Alabdullah, Tariq Tawfeeq Yousif.2018. "The Relationship Between Ownership Structure adn Firm Financial Performance". Benchmarking An International Journal Vol.25 No.1, 2018.

Alamsya, Agus rahman dan Muchlas, Zainul.2017.Pengaruh Agency cost Terhadap Kinerja Keuangan Perusahaan Keluarga Menggunakan Tobin's $Q$ dan Almant Z-Score”.Jurnal JIBEKA Vol.11 No.1, 2017.

Aprina, Desi. 2014. "Pengaruh Kepemilikan Manajerial, Kepemilikan Institusional dan Ukuran Perusahaan Terhadap Kinerja Perusahaan Yang Diukur Menggunakan Economic Value Added". Jurnal Akuntansi.

Dawar, Varun. "Agency Theory, Capital Structure and Firm Performance : Some Indian Evidance.” Managerial Finance, Vol. 40 No.12, 2014.

Efendi, Azzalia Feronicha Wianta dan Wibowo, Seto Sulaksono Adi. 2017. "Pengaruh Debt To Equity Ratio (DER) dan Debt To Asset Ratio (DAR) Terhadap Kinerja Perusahaan Di Sektor Keuangan Yang Terdaftar Di Bursa Efek Indonesia”. Jurnal Akuntansi.

Fachrudin, Khaira Amalia. 2011. "Analisis Pengaruh Struktur Modal, Ukuran Perusahaan, dan Agency Cost Terhadap Kinerja Perusahaan". Jurnal Akuntansi dan Keuangan Vol.13 No 1 Mei 2011: 37-46

Fahmi, Irham. 2014. Analisis Laporan Keuangan. Bandung : Alfabeta. Hery . 2015. Analisis Laporan Keuangan. Jakarta : Bumi Aksara.

Iswadi dan Yowanda, Nonie Carmila. 2018. "Pengaruh Kompensasi Direksi, Struktur Modal, dan Diversifikasi Terhadap Kinerja Perusahaan”. Jurnal Kebangsaan, Vol.7 No.14 JuliDesember 2018.

Jensen, Meckling.1976. "Theory of The Firm: Managerial Behavior, Agency Cost and Ownership Structure and Ownership Structure". Jourmal of Financial Economic.

Khan, et al.2012." Impact of Firm Capital Structure decision on Debt Agency problem: Evicance for Pakistan”. Journal of Basic and Applied Scientific Research.

Mahdi,Adnan dan Mujahidin.2014.Panduan Penelitian Praktis Untuk Menyusun Skripsi,Tesis,Disertasi.Bandung : ALFABETA.

Mardnly, dkk. "Corpotate Governance and Firm Performance : An Emperical Evidence From Syria. International Jorunal of Islamic and Middle Fastern Finance and Management Vol. 11, No. 4, 2018.

Narbuko, Cholid dan Abu Achmadi. 2013. Metodologi Penelitian. Jakarta : PT. Bumi Aksara. Putra. 2017. “Analisis Pengaruh Kepemilikan Institusiona dan Kepemilikan Manajerial

Terhadap Kinerja dan Nilai Perusahaan”. Studi Akuntansi \& Keuangan Indonesia.

Putri, Tyara Dwi. 2017. "Pengaruh Struktur Kepemilikan dan Struktur Modal Terhadap Agency Cost”. Menara Ekonomi ISSN: 2407-8565 Volume III No.6 - Oktober 2017.

Rani, Puspita.2015."Peran Kepemilikan Manajerial Dalam Memoderasi Pengaruh Strategi Diversifikasi Terhadap Kinerja Perusahaan”. Jurnal Akuntansi dan Keuangan Vol.4 No.2, 2015

Riadi, Edi. 2016. Statistik Penelitian. Yogyakarta: ANDI.

Sari, Fitriana Warap. 2015. "Pengaruh Struktur Kepemilikan Terhadap Kinerja Perusahaan Dengan Struktur Modal Sebafai Pemoderasi". Jurnal Ilmu \& Riset Akuntansi Vol.4 
No.8 2015.

Sanjaya, William.2017."Faktor-faktor Yang Mempengaruhi Kinerja Perusahan Pada Perusahaan Yang Terdaftar Di Bursa Efek Indonesia”.Jurnal Bisnis dan Akuntansi.

Sudana, I Made. 2011. Manajemen Keuangan Perusahaan Teori \& Praktik. Jakarta : ERLANGGA

Sugiarto. 2017. Metode Penelitian Bisnis. Yogyakarta : ANDI.

Sugiyono. 2016. Metode Penelitian Kuantitatif, Kualitatif dan R\&D. Bandung : Alfabeta.

Sukandarrumi dan Haryanto. 2014. Dasar-dasar Penulisan Proposal Penelitian. Yogyakarta : Gadjah Mada University Press.

Sunyoto,Danang.2016.Metodologi Penelitian Ekonomi.Yogyakarta: CAPS.

Syafruddin.2006. “Analisis Faktor Yang Mempengaruhi Kinerja Perusahaan”.Jurnal Akuntansi.

Tse, Chin Bun dan Rodgers, Timothy. "The Capital Structure of Chinese Listed Firms:is Manufacturing Industry Special”. Managerial Finance Vol.40 No5, 2014.

Utari, Desi. 2016. "Analisis Pengaruh Struktur Kepemilikan Saham Terhadap Kinerja Perusahaan".Skripsi Fakultas Ekonomi Universitas Putra Indonesia.

Widyati, Maria Fransisca. "Pengaruh Dewan Direksi, Komisaris Independen, Komite Audit, Kepemilikan Manajerial dan Kepemilikan Institusional Terhadap Kinerja Keuangan”. Jurnal Ilmu Manajemen Vol.1 No.1, 2013.

Zouari, Sarra Ben Slaman dan Taktak, Neila Boulila.2014."Ownership and Financial Performance in Islamic Banks". International Journal of Islamic and Middle Eastern Finance and Management Vol.7 No.2, 2014.

www.sahamok.com

www.idx.co.id 